Uşak Üniversitesi Sosyal Bilimler Dergisi

$2015,8 / 4$

\title{
İşbirlikli Öğrenme Yöntemlerinin Sosyal Bilgiler Öğretmenliği Lisans Öğrencilerinin Akademik Başarılarına Etkileri
}

\author{
Murat Bayram YILAR* \\ Ufuk ŞIMŞEK ${ }^{* *}$ \\ Yavuz TOPKAYA*** \\ İ. Sabri BALKAYA****
}

\begin{abstract}
$\ddot{O} \mathbf{z}$
$\mathrm{Bu}$ araştırmanın amacı, işbirlikli öğrenme modelinin uygulanmasında kullanılan Jigsaw ve Okuma-Yazma-Uygulama (OYU) yöntemlerinin sosyal bilgiler bölümü 2. sınıf lisans öğrencilerinin akademik başarıları üzerindeki etkisini tespit etmektir. Öntest-sontest kontrol grupsuz deneysel desenin kullanıldığı araştırmanın çalışma gurubunu 2014-2015 akademik yılında Atatürk Üniversitesi sosyal bilgiler öğretmenliği bölümünün 2 farklı şubesinde öğretim ilke ve yöntemleri dersini alan toplam 85 ikinci sınıf öğrencisi oluşturmaktadır. Kontrol grubunun yer almadığ 1 araştırma 2 deney grubu ile yürütülmüştür. Öğretim ilke ve yöntemleri dersinin içeriğinde yer alan; örnek olay inceleme, düz anlatım, tartışma, problem çözme ve gösterip yaptırma yöntemlerinin öğretimi araştırma gruplarında 5 hafta süreyle ilgili işbirlikli yöntemler uygulanarak gerçekleştirilmiştir. Veri toplama aracı olarak Akademik Başarı Testi'nin (ABT) kullanıldığı araştırmada deney gruplarındaki öğrencilerin öntestsontest puanları bağımlı ve bağımsız $t$ testi, tanımlayıcı istatistikler ve ANCOVA ile analiz edilerek değerlendirilmiştir. Araştırmadan elde edilen istatistiksel analiz sonuçlarına göre her iki işbirlikli yöntem de öğrencilerin akademik başarıları üzerinde etkili bulunmuştur. Ancak jigsaw grubu ile OYU grubu öğrencilerinin akademik başarı öntest ve sontest puanları karşılaştırıldığında aralarında anlamlı bir farkın olmadığı tespit edilmiştir.
\end{abstract}

Anahtar Kelimeler: Jigsaw, Okuma-Yazma-Uygulama, Öğretim İlke ve Yöntemleri, Akademik Başarı.

\footnotetext{
* Dr., Ondokuz Mayıs Üniversitesi, Eğitim Fakültesi., İlköğretim Bölümü

${ }^{*}$ Doç. Dr., Atatürk Üniversitesi, KKEF., İlköğretim Bölümü

*** Yrd. Doç. Dr., Kilis 7 Aralık Üniversitesi, MREF, İlköğretim Bölümü

***** Doç. Dr., Atatürk Üniversitesi, KKEF., İlköğretim Bölümü
} 


\title{
Effects of Cooperative Learning Methods on Social Studies Undergraduate Students' Academic Achievements
}

\begin{abstract}
The aim of this study is to determine the effect of Jigsaw and Reading-Writing-Presenting (RWP) methods used in the application of cooperative learning model on the academic success of 2 nd grade social studies undergraduate students. Work group of the study that experimental research design, including pre-test and post-test without control group, was used, consisted of 85 2nd grade social studies undergraduate students taking Principles and Methods of Instructions Course in two different classes in the department of Social Studies Teacher Education at Atatürk University between 2014-2015 academic year. The study was conducted with only two experimental groups. Instruction of methods, which are involved in the Principles and Methods of Instructions Course, such as case study, narrative expression,discussion, problem solving, and demonstration and practice, was carried out via application of related cooperative methods in research groups for five weeks. In this study that Academic Success Test (AST) was used as data collection tool, the pre-test and post test scores of experimental groups were analyzed by using dependent and independent $t$-test, descriptive statistics and ANOVA. According to the results of statistical analyses obtained from this study, it is found out that both cooperative methods have effect on students' academic achievements, but there was no significant difference between pre-test and post-test scores of students of Jigsaw and Reading-Writing-Presenting (RWP) groups while they compare.

Keywords: Jigsaw, Reading-Writing-Presenting (RWP), Principles and Methods of Instructions and Academic Achievement.

\section{Giriş}

Özellikle 20. yüzyılda büyük bir bilgi patlamasının yaşanması, bilim ve teknolojide köklü gelişmelerin yaşanmasına ve tüm alanlarda son derece derin ve kompleks bilgi birikiminin oluşmasına neden olmuştur. Bu durum ise tek başına zaman ve kapasite yönünden sınırlı olan insanların işbirliği içinde bir ekip olarak çalışma zorunluluğunu beraberinde getirmiştir. Bu zorunluluğun neden olduğu anlayış diğer alanlarda olduğu gibi eğitim alanına da hâkim olmaya başlamıştır. Artık modern eğitim sistemlerinde iletişim ve işbirliği gibi sosyal becerileri gelişmiş öğrencilerin yetiştirilmesi amaçlanmaktadır.
\end{abstract}


Söz konusu bu gelişmelerin eğitim alanındaki yansıması özellikle öğretim strateji, yöntem ve teknikler üzerinde yoğunluk kazanmıştır. Bu nedenle ezberci bir anlayışı öngören ve öğretmen anlatımına dayanan geleneksel öğretim yöntemi yerine öğrencilerin daha aktif olduğu yöntem ve teknikler ağırlık kazanmıştır. İlk olarak 1970'lerin sonlarından itibaren modern uygulamalarına ABD'de başlanan işbirlikli öğrenme modeli de söz konusu bu aktif öğrenme yöntemlerinden birisi olarak literatürdeki yerini almıştır (Yılar, 2015). Günümüzde işbirlikli öğrenme modelinin yanı sıra probleme dayalı öğrenme, proje tabanlı öğrenme, beyin temelli öğrenme, örnek olay incelemesi, mikro öğretim, drama, beyin fırtınası, altı şapkalı düşünme ve istasyon gibi öğrenci merkezli yaklaşım, strateji, yöntem ve teknikler de kullanılmaktadır. Fakat bunlar içinde araştırmalara daha fazla konu olması ve giderek daha fazla yaygınlık kazanması yönüyle işbirlikli öğrenmenin ön plana çıktı̆̆ı görülmektedir (Gürbüz, Aksoy \& Töman, 2013).

İşbirlikli öğrenme, küçük heterojen gruplarda öğrencilerin ortak amaçlar için bir ekip ruhu oluşturup çalıştıkları, birbirlerinin öğrenmelerinden sorumlu oldukları, bilişsel yönlerini ve sosyal becerilerini geliştirdikleri aktif bir öğrenme modelidir (Açıkgöz, 1992; Christison, 1990; Hanze \& Berger; 2007; Johnson \& Johnson, 1995; Kagan, 1994; Senemoğlu, 2005; Şimşek, 2007; Yılar, 2015). Başka bir ifadeyle işbirlikli öğrenme, bilişsel ve duyuşsal öğrenme ürünleri üzerinde olumlu etkileri kanıtlanmış, işbirliği becerilerinin ön plana çıktığı, temelinde sosyal etkileşim olan, öğrencilerin ihtiyaçlarına cevap verebilen, zihinsel yeteneklerini kullanmasını sağlayan, kendi öğrenmesi ile ilgili kararlar almasına olanak veren bir öğretim yöntemidir (Yıldız, 1999). Bu nedenle işbirlikli öğrenmenin bireyler arasındaki etkileşimlere ve yeni bilginin anlamlandırılmasına dayanan anlamlı bir sosyal aktivite olduğunu söyleyebiliriz. Böylece bu modelde öğrenme, sadece bireyin bilgiyi zihninde yeniden yapılandırmasıyla kalmayıp diğer bireylerden alınan bilgilerle oluşturulur (Moreno, 2009).

İşbirlikli öğrenme modelinin uygulama aşamasında hazıra konma veya başkalarından geçinme, sömürülme, sorumluluğun karışması (Açıkgöz, 2006), grupta başatlık (Cohen, 1986; Kocabaş, 1995), grupta uyum güçlüğü (Jacobs \& Hall, 1994; Slavin, 1990) ve gürültü (Wang, 2007) gibi bazı olumsuzlukların yaşanma ihtimali olmasına karşın yapılan çalışmalar bu modelin birçok açıdan olumlu etkileri olduğunu ortaya koymuştur. Sözgelimi literatür incelendiğinde işbirlikli öğrenme modelinin öğrencilerin üst düzey düşünme ve problem çözme becerilerini (Akdemir \& Arslan, 2012; Amirianzadeh, 2012; Bilen, 2010; Gillies, 2006; Uysal, 2010), sosyal becerilerini (Avcıoğlu, 2012; Ebrahim, 2012; Goodwin, 1999; Shekarey, 2012; Tunçel, 2006), yardımlaşma ve dayanışma becerilerini (Şimşek, Doymuş, 
Şimşek \& Özdemir, 2006; Zentall, Kuester \& Craig, 2011), demokratik tutumlarını (Gömleksiz, 1993) arttırdığı yönündeki sonuçları ortaya koyan araştırmalara sıkça rastlanmaktadır.

Ancak işbirlikli öğrenme modelinin bu yönleri araştırılırken genellikle onun geleneksel öğrenme yöntemiyle karşılaştırıldığı deneysel araştırmaların ağırlıkta olduğu görülmektedir. Çok sık rastlanılan bu araştırmaların sonucunda genel olarak işbirlikli öğrenme modelinin geleneksel yönteme göre daha etkili olduğu yönünde bir kanaatin oluştuğu söylenebilir. Bununla birlikte işbirlikli öğrenme modeli kendi içinde farklı uygulamaları olan birçok yöntem ve tekniği bünyesinde barındırmaktadır ve literatürde söz konusu bu yöntem ve tekniklerin farklı açlardan etkililiklerinin birbirleriyle karşılaştırıldığı araştırmaların ise sınırlı olduğu görülmektedir. Bunun bir eksiklik olduğu düşünülebilir. Çünkü bütün işbirlikli yöntem ve teknikler; olumlu bağımlılık, bireysel sorumluluk, yüz yüze etkileşim, sosyal beceriler ve grup sürecinin değerlendirilmesi (Johnson \& Johnson, 1989; Johnson, Johnson \& Holubec, 1993) gibi işbirlikli öğrenmenin temel ilkelerine bağlı olmakla birlikte uygulama şekilleri ise farklıdır. Dolayısıyla işbirlikli yöntem ve tekniklerin birbirlerine göre etkililiği sınıf seviyesi, ders, konu gibi farklı değişkenlere göre farklılık gösterebilmektedir. Bu nedenle işbirlikli öğrenme yöntem ve tekniklerinin birbirleriyle karşılaştırılması literatürdeki boşluğa katkı sağlamak için önemli görülmektedir.

$\mathrm{Bu}$ araştırmada, öğretim ilke ve yöntemleri dersi kapsamında yer alan "örnek olay inceleme, düz anlatım, tartışma, problem çözme ve gösterip yaptırma" yöntemleri, iki farklı grubun birinde işbirlikli öğrenme yöntemlerinden Jigsaw, diğerinde ise OYU yöntemleri kullanılarak öğrencilere öğretilmeye çalışılmıştır. Dolayısıyla bu araştırmanın amacı, öğretim ilke ve yöntemleri dersinin bazı konularının öğretiminde Jigsaw ve OYU'nun uygulandığı deney gruplarındaki öğrencilerin akademik başarıları arasında anlamlı farklılığın olup olmadığını tespit etmektir. Böylece hangi yöntemin öğrencilerin akademik başarıları üzerinde daha etkili olduğu tespit edilmeye çalışılmıştır.

\section{Problem Cümlesi}

Öğretim ilke ve yöntemleri dersi konularını Jigsaw ve OYU yöntemlerine göre alan deney gruplarındaki öğrencilerin akademik başarıları arasında anlamlı farklılıklar var mıdır? 
Sosyal Bilimler Dergisi 301

\section{Alt Problemler}

1. Jigsaw ve OYU gruplarının öntest puanları arasında anlamlı düzeyde farklılık var midır?

2. Jigsaw grubunun öntest-sontest puanları arasında anlamlı düzeyde farklılık var midır?

3. OYU grubunun öntest-sontest puanları arasında anlamlı düzeyde farklılık var midir?

4. Jigsaw ve OYU gruplarının sontest puanları arasında anlamlı düzeyde farklılık var mıdır?

\section{Sinırlılıklar}

1. Sosyal bilgiler öğretmenliği anabilim dalının zorunlu derslerinden biri olan öğretim ilke ve yöntemleri dersinin; örnek olay inceleme, düz anlatım, tartışma, problem çözme ve gösterip yaptırma konuları ile,

2. Deney gruplarına uygulanan jigsaw ve OYU yöntemleri ile,

3. 2014-2015 akademik yılı bahar döneminde, Atatürk Üniversitesi, KKEF İlköğretim Bölümü Sosyal Bilgiler Öğretmenliği Anabilim Dalı 2. sınıf öğrencileri ile sınırlandırılmıştır.

\section{Yöntem}

\section{Araştırmanın Modeli}

$\mathrm{Bu}$ çalışmada, jigsaw ve OYU yöntemlerinin rastgele seçilmiş gruplardaki öğrencilerin akademik başarılarına etkisini belirlemek amacıyla nicel araştırma yöntemlerinden kontrol grupsuz öntest-sontest deneysel desen kullanılmıştır. Kontrol grubu olmayan bu modelde grup ya da gruplara öntest, deneysel işlem başlamadan önce verilerek başarı durumu saptanmaktadır. Deneysel işlem bittikten sonra aynı test aynı gruplara sontest olarak verilir ve deneysel işlemin etkisi bu iki test arasındaki farka göre değerlendirilir. Bu desen sosyal bilimlerde sıkça kullanılmaktadır (Sönmez \& Alacapınar, 2013).

\section{Çalışma Grubu}

Araştırmanın çalışma grubu, 2014-2015 akademik yılının bahar döneminde Atatürk Üniversitesi Kazım Karabekir Eğitim Fakültesi İlköğretim Sosyal Bilgiler Öğretmenliği Programına kayıtlı iki farklı sınıftaki toplam 85 (51 erkek, 34 kız) ikinci sınıf lisans öğrencisinden oluşmaktadır. Bu sinıflardan 2/A sinıfı jigsaw yönteminin uygulandığı Jigsaw Grubu-JG $(\mathrm{n}=45), 2 / \mathrm{B}$ sinıfı ise OYU yönteminin uygulandığı Okuma-Yazma- 
Uygulama Grubu-OYUG ( $\mathrm{n}=40)$ olarak rastgele belirlenmiştir. Çalışma grubuna ilişkin bazı bilgiler Tablo 1.'de verilmiştir.

Tablo 1. Deney Grubu Öğrencilerinin Sayıları ve Cinsiyete Göre Dağılımları

\begin{tabular}{ccccc}
\hline \multirow{2}{*}{ Sinıflar } & \multirow{2}{*}{ Deney Grupları } & \multicolumn{2}{c}{ Cinsiyet } & \multirow{2}{*}{ Toplam } \\
\cline { 3 - 4 } 2/A & JG & $\mathbf{K 1 z}$ & Erkek & \\
\cline { 3 - 4 } 2/B & OYUG & 19 & 26 & 45 \\
& Toplam & 15 & 25 & 40 \\
\hline
\end{tabular}

\section{Veri Toplama Aracı}

Araştırmada, uygulamalar öncesi ve sonrasında öğrencilerin akademik başarılarını ölçmek ve anlamlı bir farklılık olup olmadığını belirlemek için araştırmacılar tarafından hazırlanan Akademik Başarı Testi (ABT) kullanılmıştır.

ABT'nin geliştirilme sürecinde ilk olarak öğretim ilke ve yöntemleri dersi kapsamında 5 hafta süreyle işlenecek olan "örnek olay inceleme, düz anlatım, tartışma, problem çözme ve gösterip yaptırma" yöntemleri ile ilgili KPSS'de çıkmış sorulardan, farklı yayınevlerine ait KPSS eğitim bilimlerine hazırlık kitaplarından ve internetten faydalanılarak 26 soruluk bir soru havuzu oluşturulmuştur. Daha sonra sosyal bilgiler eğitimi alanında 3 öğretim üyesi ve eğitim bilimleri alanında 1 öğretim üyesinden oluşan uzman grubu tarafından bu sorular içerik, dil ve hedefler açısından incelenerek soru sayısı 21'e düşürülmüş ve ön deneme formu oluşturulmuştur. Ön deneme formunun pilot uygulaması, bir önceki yıl bu dersi almış olan 3. sınıflardan 55 öğrenciye uygulanmıştır. Bu haliyle ön deneme formunun güvenirliği 0,71 olarak bulunmuştur. Yapılan madde analizleri sonucunda ayırt ediciliği 0,20'nin altında olan 6 madde ölçekten çıkarılmıştır ve tamamı 15 sorudan oluşan ABT son halini almıştır. Madde ayırt edicilik indeksi ve madde güçlük dereceleri analiz edilen 15 soruluk nihai testin güvenirlik katsayısı KR-20'ye göre 0,77 olarak bulunmuştur ve deney gruplarına öntest ve sontest olarak uygulanmıştır.

\section{Uygulama}

Araştırmada, işbirlikli öğrenme modelinin 2 farklı yöntemi (Jigsaw ve OYU) sosyal bilgiler öğretmenliği bölümü 2/A ve 2/B sınıfı öğrencilerine haftada 3'er saat olmak üzere 5 hafta süreyle uygulanmıştır. Her iki sınıfta da, öğrencilerin akademik genel not ortalamaları (AGNO) ve cinsiyetleri göz önünde tutularak heterojen gruplar oluşturulmuştur. Uygulama 
başlamadan önce öğrencilere uygulanacak işbirlikli yöntemler hakkında detaylı bilgi verilmiştir. Her iki grupta dersler araştırmacıların 2'si tarafından yürütülmüştür.

\section{a. Jigsaw yönteminin uygulanması:}

1. Öncelikle uygulama başlamadan önce dersi yürütecek olan araştırmacılar tarafından 5 hafta boyunca sürecek olan uygulamaların hangi konuları kapsadığı, uygulama süresince uyulması gereken çalışma kuralları, asıl gruplar (AG) ve uzman gruplarda (UG) grup üyelerinin rolleri ve bu süreçte nasıl değerlendirme yapılacağı açıklanmıştır.

2. Jigsaw grubundaki 45 öğrencinin her biri, AGNO ve cinsiyetleri dikkate alınarak 5 öğrenciden oluşan 9 AG'ye bölünmüştür. Grup üyeleri tarafından grupların başkanları belirlendikten sonra öğretim ilke ve yöntemleri dersi kapsamındaki örnek olay inceleme, düz anlatım, tartışma, problem çözme ve gösterip yaptırma yöntemlerinden oluşan 5 alt konu $A G^{\prime}$ deki her bir öğrenciye uzmanlaşması gereken konu olarak dağıtılmıştır.

3. Daha sonraki aşamada ise AG'de uzmanlık konusu olarak aynı alt konu başlığını alan öğrencilerin yeni gruplarında bir araya gelmeleri sağlanarak 9 kişilik UG'ler oluşturulmuştur. UG'de çeşitli kaynaklardan konularına derinlemesine çalışarak konunun uzmanı olan öğrencilerden bir de kapsamlı bir rapor hazırlamaları istenmiştir. Bu raporlar uzmanların AG'lere döndükten sonra grup arkadaşlarına konuyu öğretirken başvuracakları kaynak olarak düşünülmüştür.

4. Sonraki hafta tekrardan AG'lere dönen uzman öğrencilerden, uzmanlık konularını grup arkadaşlarına bir öğretmen gibi anlatarak onların öğrenmelerini sağlamaları istenmiştir.

AG'deki öğrencilerden yaptıkları grup tartışmalarından sonra bir rapor hazırlamaları istenmiştir.

5. En son aşamada ise grupların hazırladıkları bu raporları sınıfta sunmaları istenmiştir ve böylece jigsaw uygulaması tamamlanmıştır.

Jigsaw yönteminin uygulandığı sinıfta AG'nin ve UG'nin oluşumu Şekil 1.'de verilmiştir. 


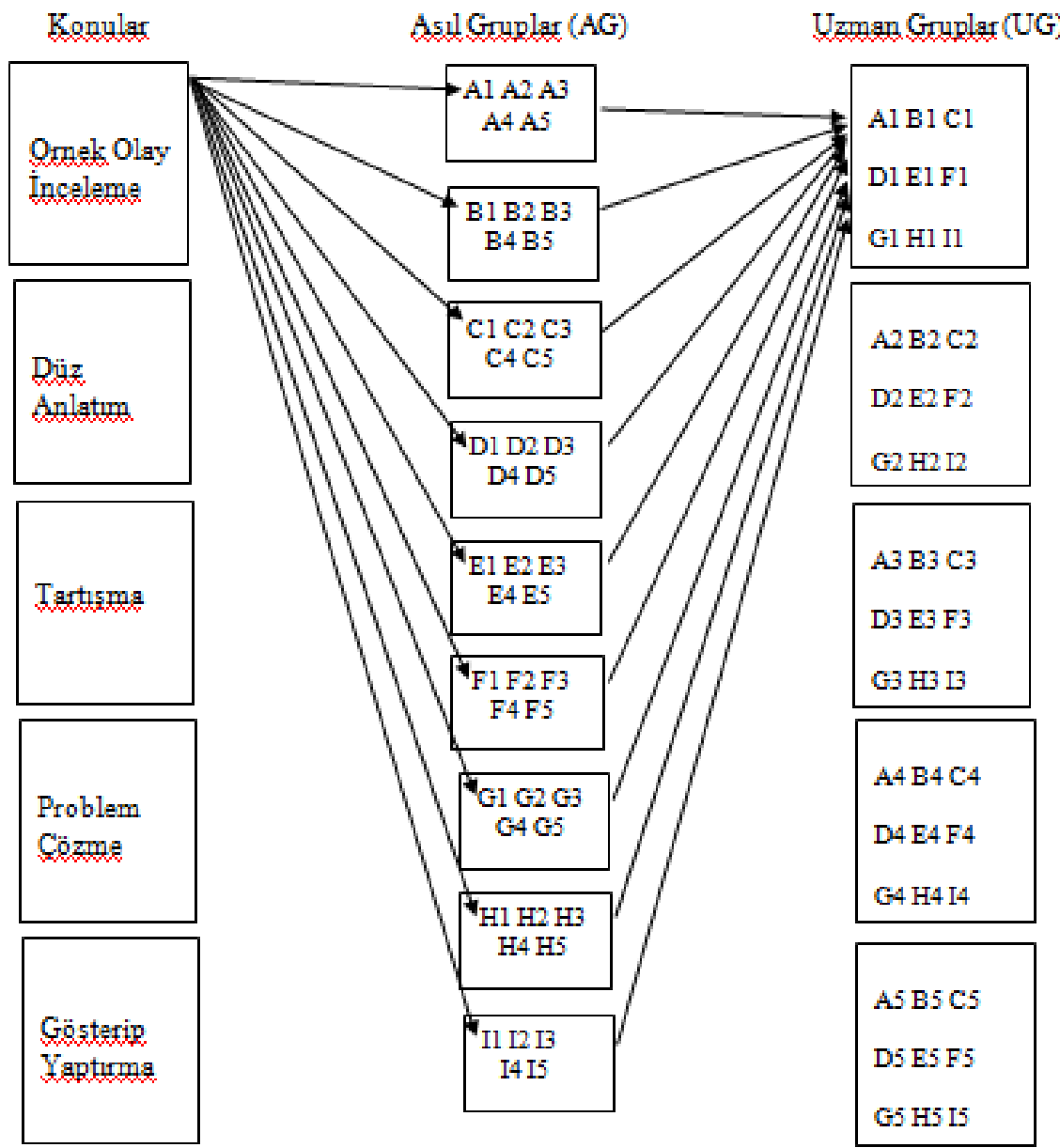

Şekil 1. Jigsaw Sınıfında AG ve UG'lerin Oluşturulması

\section{b. OYU yönteminin uygulanması:}

1. Diğer deney grubunda olduğu gibi OYU grubunda da öncelikle dersi yürütecek olan araştırmacılar tarafından 5 hafta boyunca sürecek olan uygulama konuları (1.hafta: örnek olay inceleme, 2.hafta: düz anlatım, 3.hafta: tartışma, 4.hafta: problem çözme ve 5.hafta: gösterip yaptırma), uygulama süresince uyulması gereken çalışma kuralları, grup üyelerinin rolleri ve bu süreçte nasıl değerlendirme yapılacağı açıklanmıştır.

2. OYU grubundaki 40 öğrenci, AGNO ve cinsiyetleri dikkate alınarak her biri 5 öğrenciden oluşan 8 heterojen gruba ayrılmıştır. Gruplardaki öğrencilerden grup lideri, okuyucu, yazıcı, sözcü ve raportör gibi rolleri aralarında paylaşmaları ile grup adını belirlemeleri istenmiştir. 
3. Gruplardaki öğrenciler 1. ders saatinde ilk haftanın konusuyla ilgili olarak her bir öğrencinin getirmiş olduğu farklı kaynaklardan okumalar yaparak konuyu öğrenmeleri istenmiştir.

4. Okuma aşamasını tamamlayan gruplardan 2. ders saatinde tüm kaynak ve materyallerini görünmeyecek şekilde kaldırmaları istenmiştir. Kaynak ve materyallerin kaldırılmasından sonra araştırmacıların verdiği kâğıtlara öğrendiklerini rapor etmeleri istenmiştir.

5. Toplanan grup raporları öğretmen tarafından değerlendirildikten sonra yeterli bulunmayan gruplar yeniden okuma aşamasına alınmıştır. Raporları yeterli olan ve yüksek not alan gruplar ise uygulama (sunma) aşamasına geçirilmiştir. $\mathrm{Bu}$ aşamaya geçen gruplardan ilgili konuyu materyallerle destekleyerek sunmaları istenmiştir. Sınırlı zamanın olduğu durumlarda sunum yapacak gruplar kura yoluyla belirlenmiştir. Sunumlar esnasında araştırmacılar, öğrencileri gözlemleyerek eksik kalan noktaları tamamlamış ve önemli yerleri ise özellikle vurgulamışlardır.

6. Kalan 4 haftada önceden belirlenen konular da yukarıda bahsedilen aşamalar aynı şekilde uygulanarak tamamlanmıştır.

OYU yönteminin uygulandığı sinıfta oluşturulan gruplar ve bu yönteme göre izlenen aşamalar Şekil 2.'de verilmiştir. 


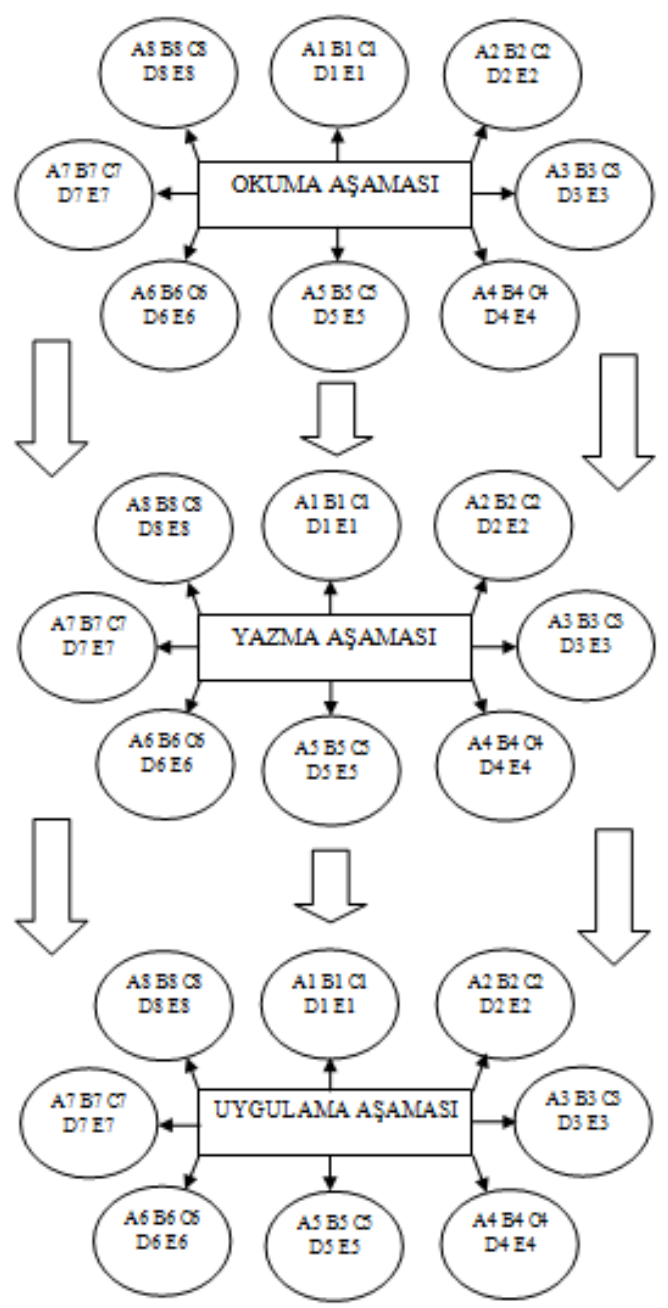

Şekil 2. Okuma-Yazma-Uygulama Yönteminin Uygulama Aşamaları ve Oluşturulan Gruplar

\section{Deneysel İşlem}

Öğretim ilke ve yöntemleri dersinin öğretiminde işbirlikli öğrenme modelinin jigsaw ve OYU yöntemlerinin akademik başarı üzerindeki etkililiklerini kıyaslamak için iki deney grubu oluşturulmuştur. Daha sonra her iki deney grubundaki öğrencilerin akademik başarılarındaki farklılıkları ve sonrasındaki değişimleri belirleyebilmek için uygulama safhasından önce ABT her iki gruba öntest olarak uygulanmıştır. Sonrasında 5 hafta boyunca 
öğretim ilke ve yöntemleri dersinin "örnek olay inceleme, düz anlatım, tartışma, problem çözme ve gösterip yaptırma yöntemleri" konuları söz konusu işbirlikli öğrenme yöntemlerine uygun olarak işlenmiştir. Son olarak uygulamalar tamamlandiktan sonra $\mathrm{ABT}$ bu kez sontest olarak deney gruplarındaki öğrencilere uygulanmıştır.

Araştırmacıların ikisi tarafından yürütülen araştırmanın deneysel süreci Tablo 2.'de verilmiştir.

Tablo 2. Araştırmanın Deneysel Süreci

\begin{tabular}{|c|c|c|c|c|}
\hline \multirow{2}{*}{$\begin{array}{l}\text { Deney } \\
\text { Grupları }\end{array}$} & \multirow{2}{*}{$\begin{array}{l}\text { Deney } \\
\text { Öncesi } \\
\text { Ön-test }\end{array}$} & \multicolumn{2}{|c|}{ Deneysel İşlem } & \multirow{2}{*}{$\begin{array}{c}\text { Deney } \\
\text { Sonrasi } \\
\text { Son-test }\end{array}$} \\
\hline & & Ders & $\begin{array}{c}\text { İşbirlikli } \\
\text { Yöntem }\end{array}$ & \\
\hline $\begin{array}{c}\text { Jigsaw Grubu } \\
\text { (JG) }\end{array}$ & $\mathrm{ABT}$ & $\begin{array}{c}\text { Öğretim ilke } \\
\text { ve yöntemleri } \\
\text { dersi }\end{array}$ & $\begin{array}{c}\text { Jigsaw ile } \\
\text { öğretim }\end{array}$ & $\mathrm{ABT}$ \\
\hline $\begin{array}{c}\text { Okuma- } \\
\text { Yazma- } \\
\text { Uygulama } \\
\text { Grubu } \\
\text { (OYUG) }\end{array}$ & $\mathrm{ABT}$ & $\begin{array}{c}\text { Öğretim ilke } \\
\text { ve yöntemleri } \\
\text { dersi }\end{array}$ & $\begin{array}{l}\text { OYU ile } \\
\text { öğretim }\end{array}$ & $\mathrm{ABT}$ \\
\hline
\end{tabular}

\section{Verilerin Analizi}

Araştırmada ilk önce deney gruplarından elde edilen verilerin normal dağılım gösterip göstermediği ve homojen olup olmadığı incelenmiştir. Deney gruplarının öntest puanlarının normal dağılım eğrisine uygunluğu SPSS programında sınanmış ve puan dağılımlarının normal dağılım eğrisi içinde yer aldığı belirlenmiştir. JG'den elde edilen öntestlerin çarpıklık katsayısı; 0,683; basıklık katsayısı ise 0,995 olarak bulunurken; OYUG'dan elde edilen öntestlerin çarpıklık katsayısı; -0,128; basıklık katsayısı ise 0, 980 olarak bulunmuştur. Deney gruplarının sontest puanlarının normal dağılım eğrisine uygunluğu üzerine ise şu sonuçlar ortaya çıkmıştır: JG'den elde edilen sontestlerin çarpıklık katsayısı; -0,381; basıklık katsayısı ise -0,822 olarak bulunurken; OYUG'dan elde edilen sontestlerin çarpıklık katsayısı; -0,125; basıklık katsayısı ise $-0,584$ olarak bulunmuştur. Dağılımdaki sapmalar, “-1, +1” aralığında kaldığı için dağılımın normal olduğu söylenebilir (Tabachnick \& Fidell, 2012). Ayrıca oluşturulan deney gruplarının öntestlerine ait varyansların homojenliğini kontrol etmek için yapılan Levene testinden elde edilen değerin $p=0,526$ 
$(\mathrm{p}>0,05)$ olduğu; sontestlerine ait varyansların homojenliğinin ise $\mathrm{p}=0,413$ $(\mathrm{p}>0,05)$ olduğu görülmektedir. Bu değerler, varyansların homojen olduğunu göstermektedir.

Verilerin normal dağılıma uygunluğu ve homojenliği tespit edildikten sonra araştırmanın alt problemlerinin test edilmesinde sırasıyla aşağıdaki istatistikler kullanılarak analizler yapılmıştır:

1. Deney gruplarının (JG ve OYUG) öntestleri arasında anlamlı bir farklılık olup olmadığını belirlemek için; Bağımsız Gruplar t Testi,

2. JG'nin kendi içinde öntest ve sontest puanları arasındaki anlamlı farklılıkların olup olmadığını belirlemek için; Bağımlı Gruplar t Testi,

3. OYUG'un kendi içinde öntest ve sontest puanları arasındaki anlamlı farklılıkların olup olmadığını belirlemek için; Bağımlı Gruplar t Testi,

4. Deney gruplarının son testleri arasında anlamlı bir farklılık olup olmadığını belirlemek için; ANCOVA analizi yapılmıştır.

\section{Bulgular}

Araştırmanın bu bölümünde, deneysel çalışma sonucunda elde edilen nicel veriler istatistiksel tekniklerle analiz edilmiş ve elde edilen bulgular tablolarla birlikte sunularak yorumlanmıştır.

\section{Araştırmanın birinci alt problemine ilişkin bulgular ve yorumlar}

Araştırmanın birinci alt problemi “Jigsaw ve OYU gruplarının öntest puanları arasında anlamlı düzeyde farklılık var mıdır?" şeklinde ifade edilmiştir. Bu alt problemin test edilmesi için bağımsız (ilişkisiz) grup t-testi yapılmış ve elde edilen bulgular Tablo 3.'de sunulmuştur.

Tablo 3. Deney Grubu Öğrencilerinin ABT Öntest Puanlarına İlişkin Bağımsız Gruplar t Testi Sonuçları

\begin{tabular}{lcccccc} 
Gruplar & $\mathrm{N}$ & $\overline{\mathrm{X}}$ & $\mathrm{Ss}$ & $\mathrm{Sd}$ & $\mathrm{t}$ & $\mathrm{p}$ \\
\cline { 2 - 5 } JG & 45 & 6,53 & 1,791 & 0,267 & $-0,377$ & \multirow{2}{*}{0,707} \\
\cline { 2 - 5 } OYUG & 40 & 6,68 & 1,655 & 0,262 & & \\
\hline
\end{tabular}

Tablo 3. incelendiğinde, JG ve OYUG'daki öğrencilerin ABT öntest puan ortalamalarının birbirine oldukça yakın olduğu ve öntest puan ortalamaları arasında anlamlı bir farklılığın olmadığı görülmektedir ( $\mathrm{t}=-$ $0,377 ; p>0,050)$. Bu sonuçlar uygulama öncesinde her iki deney grubunda bulunan öğrencilerin öğretim ilke ve yöntemleri dersiyle ilgili akademik bilgi düzeylerinin birbirine benzer olduğunu göstermektedir. 


\section{Araştırmanın ikinci alt problemine ilişkin bulgular ve yorumlar}

Araştırmanın ikinci alt probleminde "Jigsaw grubunun öntestsontest puanları arasında anlamlı düzeyde farklılık var mıdır?" sorusuna cevap vermek için veriler bağımlı (ilişkili) grup t-testi yapılmış ve elde edilen bulgular Tablo 4.'de sunulmuştur.

Tablo 4. JG Öğrencilerinin ABT Öntest ve Sontest Puanlarına İlişkin Bağımlı Gruplar t Testi Sonuçları

\begin{tabular}{|c|c|c|c|c|c|c|}
\hline Jigsaw Grubu & $\mathrm{N}$ & $\overline{\mathrm{X}}$ & Ss & $\mathrm{Sd}$ & $t$ & $\mathrm{p}$ \\
\hline Öntest & 45 & 6,53 & 1,791 & 0,267 & \multirow{2}{*}{875} & \multirow{2}{*}{0,000} \\
\hline Sontest & 45 & 10,36 & 1,773 & 0,264 & & \\
\hline
\end{tabular}

Tablo 4. incelendiğinde jigsaw yöntemi ile öğrenim gören öğrencilerin öntest puan ortalamaları ile sontest puan ortalamaları arasında anlamlı bir farklılık olduğu görülmektedir [ $\mathrm{t}=-10,875 ; \mathrm{p}<0.05]$. Bu farklılığa göre JG'deki öğrencilerin uygulama öncesi $A B T$ öntest puan ortalamaları 6,53 iken, jigsaw ile yapılan öğretim sonrasında sontest puan ortalamalarının $10,36^{\prime}$ ya yükseldiği görülmektedir. Bu bulgular, jigsaw yönteminin öğretim ilke ve yöntemleri dersinde öğrencilerin akademik başarısının artmasında etkili bir öğretim yöntem olduğunu göstermektedir.

\section{yorumlar}

3. Araştırmanın üçüncü alt problemine ilişkin bulgular ve

Araştırmanın üçüncü alt probleminde "OYU grubunun öntestsontest puanları arasında anlamlı düzeyde farklılık var mıdır?" sorusuna cevap vermek için veriler bağımlı (ilişkili) grup t-testi yapılmış ve elde edilen bulgular Tablo 5.'de sunulmuştur.

Tablo 5. OYUG Öğrencilerinin ABT Öntest ve Sontest Puanlarına İlişkin Bağımlı Gruplar t Testi Sonuçları

\begin{tabular}{lcccccc} 
OYU Grubu & $\mathrm{N}$ & $\overline{\mathrm{X}}$ & $\mathrm{Ss}$ & $\mathrm{Sd}$ & $\mathrm{t}$ & $\mathrm{p}$ \\
\cline { 2 - 5 } $\begin{array}{l}\text { Öntest } \\
\text { Sontest }\end{array}$ & 40 & 6,68 & 1,655 & 0,262 & \multirow{2}{*}{$-9,294$} & \multirow{2}{*}{0,000} \\
\hline
\end{tabular}

Tablo 5. incelendiğinde OYU yöntemi ile öğrenim gören öğrencilerin öntest puan ortalamaları ile sontest puan ortalamaları arasında anlamlı bir farklılık olduğu görülmektedir [t=-9,294; $\mathrm{p}<0.05]$. Bu farklılığa göre OYUG'daki öğrencilerin uygulama öncesi ABT öntest puan ortalamaları 6,68 iken, OYU ile yapılan öğretim sonrasında sontest puan ortalamalarının 
9,75’e yükseldiği görülmektedir. Bu bulgular, OYU yönteminin öğretim ilke ve yöntemleri dersinde öğrencilerin akademik başarısının artmasında etkili bir öğretim yöntem olduğunu göstermektedir.

\section{yorumlar}

4. Araştırmanın dördüncü alt problemine ilişkin bulgular ve

Araştırmanın dördüncü alt problemi "Jigsaw ve OYU gruplarının sontest puanları arasında anlamlı düzeyde farklılık var mıdır?" şeklinde ifade edilmiştir. $\mathrm{Bu}$ alt problemi test edip deney gruplarının sontestleri arasındaki farka bakmak için ilk olarak Tablo 6.'da ABT sontest puanlarına ilişkin tanımlayıcı istatistikler verilmiştir.

Tablo 6. ABT Sontest Puanlarına İlişkin Tanımlayıcı İstatistikler

\begin{tabular}{lccc}
\hline Gruplar & $\mathrm{N}$ & $\overline{\mathrm{X}}$ & $\mathrm{Ss}$ \\
\cline { 2 - 4 } JG & 45 & 10,36 & 1,773 \\
OYUG & 40 & 9,75 & 1,548 \\
\hline
\end{tabular}

Tablo 6.'da görüldügü gibi uygulama sonrasında deney gruplarının başarı düzeyleri üzerinde işbirlikli yöntemlerin etkisini belirlemek için yapılan sontestler sonucunda, jigsaw yönteminin uygulandığı grubunun ortalaması $X=10,36$; OYU yönteminin uygulandığ grubun ortalaması ise $X=9,75$ olarak bulunmuştur. Elde edilen bu puan ortalamalarının birbirine yakın olduğu görülmekle birlikte puanlar arasında istatistiksel olarak anlamlı bir farkın olup olmadığını ortaya koymak amacıyla bağımsız gruplar için covaryans (ANCOVA) analizi yapılmıştır ve sonuçlar Tablo 7.'de verilmiştir.

Tablo 7. Deney Grubu Öğrencilerinin ABT Sontest Puanlarına İlişkin ANCOVA Analizi Sonuçları

\begin{tabular}{|c|c|c|c|c|c|}
\hline $\begin{array}{l}\text { Varyansın } \\
\text { Kaynağ }\end{array}$ & $\begin{array}{l}\text { Kareler } \\
\text { Toplamı }\end{array}$ & sd & $\begin{array}{c}\text { Kareler } \\
\text { Ortalaması }\end{array}$ & $\mathrm{F}$ & $\mathrm{p}$ \\
\hline ABT Öntest & 4,186 & 1 & 4,186 & 1,508 & 0,223 \\
\hline Gruplar & 8,230 & 1 & 8,230 & 2,965 & 0,089 \\
\hline Hata & 227,626 & 82 & 2,776 & & \\
\hline Toplam & 239,576 & 84 & & & \\
\hline
\end{tabular}

Tablo 7.'de ANCOVA analizi sonuçları incelendiğinde deney gruplarının akademik başarı sontest puanları arasında anlamlı bir farkın olmadığı görülmektedir $(\mathrm{p}=0,089)$. 
Genel olarak elde edilen bulgular incelendiğinde deney gruplarının akademik başarı öntest ve sontest puanlarında anlamlı farklılığın olmadığı; bununla birlikte JG'nin öntestte OYUG'un gerisinde olduğu, sontestte ise OYUG'u geçtiği görülmektedir. Bu durum, jigsaw yönteminin öğrencilerin hem asıl gruplarda hem de uzman gruplarda farklı öğrencilerle birlikte çalışmalarını gerektirmesi, öğrencilerin uzman oldukları konuyu kendi gruplarında bir öğretmen gibi anlatarak grup arkadaşlarına öğretmesi ve böylece yaparak yaşayarak öğrenmelerin gerçekleşmesi gibi nedenlere dayandırılabilir.

\section{Sonuç ve Tartışma}

Bu çalışmada sosyal bilgiler öğretmenliği bölümünde okuyan 2. sınıf öğrencilerinin öğretim ilke ve yöntemleri dersindeki başarıları üzerinde jigsaw ve OYU yöntemlerinden hangisinin daha etkili olduğunu test etmeye yönelik deneysel bir çalışma yapılmıştır. Aşağıda bu çalışmadan elde edilen sonuçlara yer verilmiştir.

Öncelikle SPSS programı ve Levene testi analiziyle her iki deney grubunun aldıkları puanlar doğrultusunda normal dağılım gösterdikleri ve homojen yapıda oldukları tespit edilmiştir.

Araştırmanın birinci alt problemi kapsamında jigsaw ve OYU gruplarının akademik başarı öntest puanları arasında anlamlı düzeyde farklılık olup olmadığını belirlemek için bağımsız gruplar $\mathrm{t}$ testi analizi yapılmıştır. Analiz sonucunda JG ile OYUG'un ABT öntest puan ortalamaları arasında anlamlı bir fark bulunmamıştır. Bu bulgu uygulamaya başlamadan önce her iki deney grubunun da öğretim ilke ve yöntemleri dersinin ilgili konularında akademik açıdan benzer özelliklere sahip olduklarını göstermektedir.

Araştırmanın ikinci alt problemi kapsamında deney gruplarından sadece jigsaw grubunun öntest-sontest puanları arasında anlamlı düzeyde farklılık olup olmadığı araştırılmıştır. Yapılan analizler sonucunda JG öntest ve sontest puanlarının anlamlı düzeyde değiştiği ve sontestlerde aritmetik ortalamalarının yükseldiği görülmektedir. Bu bulgular, öğretim ilke ve yöntemleri dersinde jigsaw yönteminin öğrencilerin akademik başarılarını arttırmada etkili bir yöntem olduğunu göstermektedir. Bu sonuç jigsawın akademik başarı açısından etkili bir yöntem olduğunu ortaya koyan araştırmalarla (Altıparmak \& Nakiboğlu, 2005; Dilek \& Gürdal, 2004; Ghaith \& Bouzeineddine, 2003; Slish, 2005; Tran \& Lewis, 2012) benzerlik göstermektedir.

Araştırmanın üçüncü alt problemi kapsamında ise diğer deney grubu olan OYU grubunun öntest-sontest puanları arasında anlamlı 
düzeyde farklılık olup olmadığı araştırılmıştır. Yapılan analizler sonucunda OYUG öntest ve sontest puanlarının da anlamlı düzeyde değiştiği ve sontestlerde aritmetik ortalamalarının yükseldiği görülmektedir. $\mathrm{Bu}$ bulgular, öğretim ilke ve yöntemleri dersinde jigsaw yöntemi gibi OYU yönteminin de öğrencilerin akademik başarılarını arttırmada etkili bir yöntem olduğunu göstermektedir. Bu sonuçlara bakarak hem jigsaw yönteminin hem de OYU yönteminin öğrencilerin akademik başarıların arttırmada önemli bir etkisinin olduğu yorumu yapılabilir. Bu sonuç OYU yönteminin akademik başarı açısından etkili bir yöntem olduğunu ortaya koyan araştırmalarla (Aksoy \& Doymuş, 2012; Aksoy \& Gürbüz, 2013; Şahin, 2013; Şimşek, Y1lar \& Küçük, 2013) benzerlik göstermektedir.

Araştırmanın dördüncü ve son alt problemi kapsamında jigsaw ve OYU yönteminin öğrencilerin öğretim ilke ve yöntemleri dersinde "örnek olay inceleme, düz anlatım, tartışma, problem çözme ve gösterip yaptırma" konuları öğretiminde akademik başarı sontest puanları açısından hangi yöntemin daha etkili olduğunu belirlemek amaciyla covaryans analizi yapılmıştır. Deney gruplarının öntest puanlarında anlamlı farklılık olmamasına rağmen öntestlerin etkisini tamamen ortadan kaldırmak için ANCOVA analizi yapılmıştır. Böylece yapılan ANCOVA analizi sonucunda grupların akademik başarı sontest puanları arasında anlamlı bir farkın

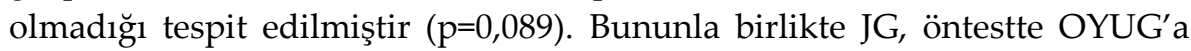
göre daha düşük bir ortalamaya sahip iken, sontest de ise daha yüksek bir ortalama yakalamıştır. Başka bir ifadeyle sontest ortalamaları JG lehine farklılaşmıştır. Ancak bu farklılık istatistiksel olarak anlamlı değildir.

Akademik başarı açısından iki yöntem arasında anlamlı farklılık çıkmamasının sebebi, 5 hafta boyunca öğretim ilke ve yöntemleri dersinde işlenen konuların karmaşık olmaması ve kolay öğrenilebilir olmasından kaynaklandığı söylenilebilir. Bunun yanı sıra sınıftaki uygulama adımları farklılıklar gösterse bile genel olarak her iki yöntemin de öğretim etkinlikleri sırasında öğrencilerin aktif olmalarını, grup başarısı için yüksek motivasyon taşımalarını gerektirmesi ayrıca daha fazla araştırma ve daha çok kaynaktan yararlanmalarını sağlaması gibi benzer özellikler göstermelerinden kaynaklanmış olabilir (Koç, 2014; Meral \& Şimşek, 2014). Bu sonuç akademik başarı açısından işbirlikli öğretim yöntemler arasında anlamlı fark bulamayan bazı araştırmalarla (Akkuş, 2013; Dellalbaşı \& Soylu, 2012; Gürbüz, Aksoy \& Töman, 2013; Meral \& Şimşek, 2014; Şimşek, 2012a, 2012b) paralellik göstermektedir. Benzer şekilde Yılar'ın (2015) ortaokul sosyal bilgiler dersinde yaptığı araştırmada da akademik başarı açısından jigsaw ve OYU grupları arasında anlamlı fark bulunamamış ancak grup araştırması yöntemiyle OYU arasında anlamlı farklılık tespit edilmiştir. Ayrıca bu 
araştırma literatürde işbirlikli öğrenme yöntemleri arasında akademik başarı açısından anlamlı farklılık bulan bazı çalışmaların (Aksoy \& Gürbüz, 2013; Koç, 2014; Akçay \& Doymuş, 2014; Şimşek, Yılar \& Küçük, 2013) sonuçları ile de farklılık göstermektedir.

Bu sonuçlar doğrultusunda bazı öneriler sunulabilir:

- JG öntestlerde geriden gelip sontestlerde OYUG'u geçmiştir. Fakat bu artışla birlikte değişen ortalamalar istatistiksel olarak anlamlı bulunmamıştır $(\mathrm{p}=0,089)$. Ancak uygulama süresinin daha uzun olması durumunda bu değişimin anlamlı olabileceği düşünülmektedir. Bu yüzden uygulama süresi daha uzun süren çalışmalarla bu yöntemlerin karşılaştırılması daha güvenilir sonuçlar verebilir.

- $\mathrm{Bu}$ işbirlikli yöntemlerin farklı konu alanlarında ve farklı sınıf seviyelerinde kullanıldığı araştırmalar yapılabilir.

- İşbirlikli öğrenme modelinin diğer yöntemlerinin birbirleriyle farklı açılardan karşılaştırıldığı araştırmalar yapılabilir.

\section{Kaynakça}

Açıkgöz, K. Ü. (1992). İşbirlikli öğrenme: Kuram, araştırma ve uygulama. Malatya: Uğurel Matbaası.

Açıkgöz, K.Ü. (2006). Aktiföğrenme. (8. Baskı). İzmir: Kanyılmaz Matbaası.

Akçay, N.O. \& Doymuş, K. (2014). The effect of different methods of cooperative learning model on academic achievement in physics. Journal of Turkish Science Education, 11(4), 17-30.

Akdemir, E. \& Arslan, A. (2012). From past to present: Trend analysis of cooperative learning studies. Procedia - Social and Behavioral Sciences, $55,212-217$.

Akkuş, A. (2013). Fen ve Teknoloji Öğretmenlerinin İşbirlikli Öğrenme Modeli Hakkında Bilgilendirilmesi, Bu Modeli Sinufta Uygulamalarn ve Elde Edilen Sonuçlarm Değerlendirilmesi: Muş il Örneği. Yayımlanmamış Doktora Tezi, Atatürk Üniversitesi, Erzurum.

Aksoy, G. \& Doymuş, K. (2012). İşbirlikli okuma-yazma-uygulama ve birlikte öğrenme yöntemlerinin öğrencilerin akademik başarıları üzerine etkisi. Trakya Üniversitesi Eğitim Fakültesi Dergisi, 2(1), 47-59.

Aksoy G. \& Gürbüz, F. (2013). The effects of reading-writing-application technique and learning together technique on increasing 6th grade students' academic achievement and students' opinions about these techniques. Energy Education Science and Technology Part B, 5(1) 19-26. 
Altıparmak, M. \& Nakiboğlu, M. (2005). Lise biyoloji laboratuarlarında işbirlikli öğrenme yönteminin tutum ve başarıya etkisi. Türk Ĕ̆itim Bilimleri Dergisi, 3(1),105-123.

Amirianzadeh, M. (2012). Hexagon theory - student leardship development. Procedia-Social and Behavioral Sciences, 31, 333-339.

Avcıoğlu, H. (2012). Zihinsel yetersizliği olan çocuklara sosyal beceri kazandırmada işbirliğine dayalı öğrenme ve drama yöntemlerinin etkililiği. Ĕ̆itim ve Bilim, 37(163), 110-125.

Bilen, S. (2010). The effect of cooperative learning on the ability of prospect of musicteachers to apply Orff-Schulwerk activities. Procedia-Social and Behavioral Sciences, 2, 4872-4877.

Christison, M.A. 1990. Cooperative learning in the EFL classroom. In: Kral, T. (Ed.). Teacher Development Making the Right Move. U.S. Information Agency, Washington, DC, pp. 139-147.

Cohen, E. G. (1986). Desining Groupwork: Strategies For Heterogeneoas Classroom. New York: Colombia University Teacher College.

Dellalbaşı, O. \& Soylu, Y. (2012). Jigsaw ve grup araştırması tekniklerinin ilköğretim 8. sınıf öğrencilerinin matematik derslerindeki akademik başarılarına etkisi. The Journal of Academic Social Science Studies, 5(7), 229-245.

Dilek, C. \& Gürdal, A. (2004). Fizik eğitiminde parçalı öğretim tekniğinin öğrenci başarısına etkisi. VI. Fen Bilimleri ve Matematik Eğitimi Kongresi. (9-11 Eylül 2004). Bildiriler-I (s.330-336). İstanbul: Marmara Üniversitesi.

Ebrahim, A. (2012). The effect of cooperative learning strategies on elementary students' science achievement and social skills in Kuwait. International Journal of Science and Mathematics Education 10(2), 293-314.

Ghaith, G. \& Bouzeineddine, A.R. (2003). Relationship between reading attitudes, achievement, and learners' perceptions of their jigsaw II cooperative learning experience. Reading Psychology, 24(1), 105-121.

Gillies, R.M. (2006). Teachers' and students' verbal behaviours during cooperative and small-group learning. British Journal of Educational Psychology, 76(2), 271-287.

Goodwin, M.W. (1999). Cooperative Learning and Social Skills What Skills to Teach and How to Teach Them. Intervention in School and Clinic, 35(1), 29-33.

Gömleksiz, M. (1993). Kubaşık öğrenme yöntemi ile geleneksel yöntemin demokratik tutumlar ve erişiye etkisi. Yayımlanmamış Doktora Tezi, Çukurova Üniversitesi Sosyal Bilimler Enstitüsü, Adana. 
Gürbüz, F., Aksoy, G \& Töman, U. (2013). Effects of reading-writingapplication and learning together techniques on 6th grade students' academic achievements on the subject of "Matter and Temperature". Mevlana International Journal of Education (MIJE) 3(2), 139-150.

Hanze, M. \& Berger, R. (2007). Cooperative learning, motivational effects, and student characteristics: An experimental study comparing cooperative learning and direct instruction in 12th grade physics classes. Learning and Instruction, 17(1), 29-41.

Jacobs, G.M. \& Hall, S. (1994). Implementing Cooperative Learning. Forum, 32(4), 2-5.

Johnson, D.W., Johnson, R.T. \& Holubec, E. J. (1993). Cooperation in the classroom. Edina, Minnesota: Interaction Book Company.

Johnson, D.W. \& Johnson, R.T. (1989). Cooperation and competition: Theory and research. Edina, Minnesota: Interaction Book Company.

Johnson, D.W. \& Johnson, R.T. (1995). Creative controversy: Intellectual challenge in the classroom. Edina, MN: Interaction Book Company.

Kagan, S. (1994). Cooperative learning. Cordillera: Kagan.

Kocabaş, A. (1995). İşbirlikli öğrenmenin blokflüt öğretimi ve öğrenme stratejileri üzerindeki etkileri. Yayımlanmamış Doktora Tezi. Dokuz Eylül Üniversitesi, İzmir.

Koç, Y. (2014). Okuma-yazma-uygulama ve öğrenci takımları başarı bölümleri yöntemlerinin öğrencilerin akademik başarıları üzerine etkisi: Madde ve 1sı ünitesi. Ekev Akademi Dergisi, 18(58), 191-210.

Meral, E. \& Şimşek, U. (2014). Sosyal bilgiler dersinde işbirlikli öğrenme tekniklerinin 6. Sınıf öğrencilerinin akademik başarılarına etkisi. Journal of Computer and Education Research, 2(4), 134-151.

Moreno, R. (2009). Constructing Knowledge with an Agent-Based Ġnstructional Program: A comparison of Cooperative and Individual Meaning Making. Learning and Instruction, 19, 433-444.

Senemoğlu, N. (2005). Gelişim ve öğrenme. Ankara: Gazi Kitapevi.

Shekarey, A. (2012). Effects of cooperative learning on the development of students' social skills. Education Strategies in Medical Sciences, 5(1), 3137.

Slavin, R.E. (1990). Cooperative learning: Theory, research, and practice (Vol. 14). Boston: Allyn and Bacon.

Slish, D. F. (2005). Assessment of the use of the jigsaw method and active learning in non-majors, introductory biology. Bioscene: Journal of College Biology Teaching, 31(4), 4-10.

Sönmez, V. \& Alacapınar, F.G. (2013). Örneklendirilmiş Bilimsel Araştırma Yöntemleri, Ankara: Anı Yayıncılık. 
Şahin, E. (2013). Kimyasal denge ünitesinin öğretiminde uygulanan okuma-yazmauygulama yönteminin öğrencilerin akademik başarıları üzerine etkisi. Yayımlanmamış Yüksek Lisans Tezi, Atatürk Üniversitesi Eğitim Bilimleri Enstitüsü, Erzurum.

Şimşek, U. (2012). Effects of cooperative learning methods on social studies undergraduate students' achievement in political science. Energy Education Science and Technology Part B. (Special Issue), 322-328.

Şimşek, U. (2012). The effects of reading-writing-presentation and group investigation methods on students' academic achievements in citizenship lessons. Journal of Educational Sciences Research, 2(2), 189201.

Şimşek, U., Doymuş, K., Şimşek, Ü., \& Özdemir, Y. (2006). Lise düzeyinde eğitim gören öğrencilerin demokratik tutumlarına işbirlikçi öğrenme yönteminin etkisinin incelenmesi. Atatürk Üniversitesi Sosyal Bilimler Enstitüsü Dergisi, 7(1), 165-172.

Şimşek, U., Yılar, B. \& Küçük, B. (2013). The effects of cooperative learningmethods on students' academic achievements in social psychological lessons. International Journal on New Trends in Education and Their Implications, 4(3), 5-9.

Şimşek, Ü. (2007). Çözeltiler ve kimyasal denge konularında uygulanan jigsaw ve birlikte öğrenme tekniklerinin öğrencilerin maddenin tanecikli yapıda öğrenmeleri ve akademik başarıları üzerine etkisi. Yayımlanmamış Doktora Tezi, Atatürk Üniversitesi Fen Bilimleri Enstitüsü, Erzurum.

Tabachnick, B.G. \& Fidell, L.S. (2012). Using multivariate statistics. New Jersey: Pearson.

Tran, V.D. \& Lewis, R. (2012). The effects of jigsaw learning on students' attitudes in a Vietnamese higher education Classroom. International Journal of Higher Education, 1(2), 9-20.

Tunçel, Z. (2006), İşbirlikli öğrenmenin beden eğitimi başarısı, bilişsel süreçler ve sosyal davranışlar üzerindeki etkileri, Yayımlanmamış Doktora Tezi, Dokuz Eylül Üniversitesi Eğitim Bilimleri Enstitüsü, İzmir.

Uysal, G. (2010). Illköğretim sosyal bilgiler dersinde işbirlikli öğrenmenin erişiye, problem çözme becerilerine, öğrenme stillerine etkisi ve öğrenci görüşleri. Yayımlanmamış Doktora Tezi, Dokuz Eylül Üniversitesi Eğitim Bilimleri Enstitüsü, İzmir.

Wang, T.P. (2007). The comparison of the difficulties between cooperative learning and traditional teaching methods in college English teachers. The Journal of Human Resource and Adult Learning, 3(2), 2330. 
Yılar, M.B. (2015). Sosyal bilgiler dersinde işbirlikli öğrenme yöntemlerinin öğrencilerin akademik başarılarına, demokratik tutumlarına ve sosyal becerilerine etkileri. Yayımlanmamış Doktora Tezi, Atatürk Üniversitesi Eğitim Bilimleri Enstitüsü, Erzurum.

Yıldız, V. (1999). İşbirlikli Öğrenme ile Geleneksel Öğrenme Grupları Arasındaki Farklar. Hacettepe Üniversitesi Ĕ̆itim Fakültesi Dergisi, 16(17), 155 - 163.

Zentall, S.S., Kuester, D.A. ve CraigB. A. (2011).Social behavior in cooperative groups: Students at risk for ADHD and their peers. Journal of Educational Research, 104(1), 28-41. 
M. B. YILAR, U. ŞIMŞEK, Y. TOPKAYA, İ. S. BALKAYA $\mid 318$ 